Дима О.O.

канд.економ.наук, дочент

ДВНЗ «Київський начіональний економічний університет ім. В. Гетьмана»

\title{
ЩОДО НОВОГО ЗМІСТУ КАТЕГОРІЙ «ОПТ» ТА «РОЗДРІБ»
}

\author{
ON NEW CONTENT OF «WHOLESALE»AND «RETAIL»CATEGORIES \\ ОТНОСИТЕЛЬНО НОВОГО СОДЕРЖАНИЯ КАТЕГОРИЙ \\ «ОПТ» И «РОЗНИЦУ»
}

У статті проаналізовано категорії «опт» та «роздріб», щзо дало змогу запропонувати сучасний погляд на розуміння розміру партії товару з урахуванням тенденцій економічних відносин. Представлено аналіз наявних визначень категорії «опт». Здійснено порівняння категорій «опт» та «роздріб» за їх ключовими характеристиками. Аналіз дав змогу виявити ключові відмінності: розмір партії та мета купівлі. Такі відмінності нівелюються сучасними тенденціями розвитку соціально-економічних процесів: масове виготовлення на замовлення, відтерміноване виробництво, спільне споживання, домінування роздрібної торгівлі та поступове витіснення оптового посередника з ланцңюга постачання. 3 розвитком ринку інформаційних продуктів необхідно розробити нові показники вимірювання його обсягів, щзо зумовлено відмінностями прочесів виробництва, розподілу і спожсивання матеріальних продуктів.

Ключові слова:опт, роздріб, інформація, масове виготовлення на замовлення, відтерміноване виробництво, спільне споживання

В статье проведен анализ категорий «опт» и «розница», что позволило предложить современный взгляд на понимание размера партии товара с учетом тенденций экономических отношений. Осуществлен анализ существующих определений категории «опт». Проведено сравнение категорий «опт» $u$ «розница» по их ключевым характеристикам. Анализ позволил выявить ключевые отличия: размер партии и иель покупки. Такие различия нивелируются современныли тенденциями развития социальноэкономических прочессов: массовое изготовление на заказ, отложенное производство, совместное потребление, доминирование розничной торговли и постепенное вытеснение оптового посредника из иепи поставки. С развитием рынка информационных продуктов необходимо разработать новые показатели измерения объемов потребления, что обусловлено отличием проиесса производства, распределения и потребления материальных продуктов.

Ключевые слова: опт, розница, информация, массовое изготовление на заказ, отложенное производство, совместное потребление.

The article analyses «wholesale» and «retail» categories, providing amodern understanding of the size of consignment, taking into account trends in economic relations. Analysis of existing definitions of «wholesale» was carried out. A comparison of the main characteristics of «wholesale» and «retail» categories revealed their key differences: the size of the lot and the purpose of purchase. Such differences are cancelled out by the current trends of socio-economic processes: mass customization, postponed production, collaborative consumption, domination of retail, and the 
gradual ousting of the wholesale intermediary from the supply chain. Development of the information market calls for the introduction of new indicators measuring its volume, due to the differences in the processes of production, distribution and consumption of material goods.

Keywords: nature category, wholesale, retail, information, mass customization, postponed production, collaborative consumption

Вступ.Система розподілу поділяється на оптову та роздрібну ланку, але останнім часом такий підхід втрачає свою актуальність. 3 появою сучасних моделей ведення бізнесу, коли виробники віддають перевагу веденню справ безпосередньо з кінцевим споживачем, передаючи частину функцій доведення товарустороннім організаціям, визначення категорій «опт» та «роздріб» втрачає свій зміст. Не варто забувати про те, що $60 \%$, а іноді й $80 \%$ ВВП розвинутих країн генерується за рахунок сфери послуг, які здебільшого надаються кожному окремому споживачу в індивідуальному порядку відповідно до його особливих потреб, що також відміняє поняття категорій «опт» та «роздріб».

Не менше питань виникає з інформаційним продуктом, який має свої особливості збору, оброблення, зберігання та споживання. Традиційне розуміння категорій «опт» та «роздріб» щодо інформаційного продукту практично неможливо застосувати.

На сьогоднішній день категорії «опт» та «роздріб» мають однозначне трактування, яке практично не підлягає дискусійному обговоренню. У тлумачних словниках можна знайти усталені визначення обох категорій, які не змінювалися останнє століття. Деякі відмінності до підходів у трактуванні категорії «опт» та «роздріб» можна знайти в галузевій літературі, що зумовлено традиційними обсягами закупівлі партій товару та їх торгівлі у роздрібній мережі. Але основні відмінності обмежені реалізаціями функцій бізнесу на етапі оптової та роздрібної торгівлі, відсуваючи розуміння власне категорій «опт» та «роздріб» на другий план.

Постановка завдання. Метою статті $є$ дослідження змісту категорій «опт» та «роздріб» 3 урахуванням змін у системі споживання та розповсюдженням інформаційних та сервісних продуктів.

Методологія.У процесі дослідження використовуєтьсяметоди теоретичного узагальнення, порівняння та абстрагування для отримання нового розуміння категорій «опт» та «роздріб».

Результати дослідження.Останнім часом, як вже зазначалося, оптова ланка ланцюга створення цінності зазнає трансформації. Виробничі підприємства та роздрібні торгівці перебирають на себе функції оптовика.

На відмінувід оптовоїторгівлі, товар, придбаний усистемі роздрібноїторгівлі, не розрахованийна подальший перепродаж, а призначений длябезпосередньоговикористання[8].Причому неважливо, як саме продаються товари і послуги - методом особистого продажу, поштою, по телефону або 
через торговий автомат, і де саме вони продаються -у магазині, на вулиці чи вдома у споживача [1].

Басовський Л. Е. вважає що оптові торгівці відрізняються від роздрібних занизкою характеристик[1]:

- по-перше, оптовик приділяє менше уваги стимулюванню продажів, атмосфері й розташуванню свого торгового підприємства, оскільки він має справу переважно з професійними клієнтами;

- по-друге, за обсягом оптові угоди перевищують роздрібні, а торгова зона оптовика зазвичай більша ніж у роздрібного торговця;

- по-третє, щодо правових узгоджень і податків уряд підходить до оптових і роздрібних торговців з різних позицій.

У таблиці 1 представлені визначення поняття «опт», запропоновані в різних тлумачних словниках. Згідно із запропонованими визначеннями, опт це крупна партія. Окремо виділимо одне 3 визначень, запропоноване Єфремовою Т.Ф.Відповідно до трактування автора, опт - це купівля продукції як перший етап руху товару виробника до покупця.

Таблиця 1

Трактування поняття категорії «опт»

\begin{tabular}{|c|c|}
\hline Автор & Визначення \\
\hline Вікісловник & Порівняно велика партія, велика кількість товару[6]. \\
\hline Дмитрієв Д. В. & Це купівля і продаж товарів не поштучно, а партіями[2]. \\
\hline Кузнєцов С.А. & $\begin{array}{c}\text { 1) купівля і продаж товарів великими кількостями, партіями; } \\
\text { 2) товар, який продається в таких кількостях [4]. }\end{array}$ \\
\hline Єфремова Т.Ф. & $\begin{array}{c}\text { 1) товар, який продається великими партіями, у великій кількості; } \\
\text { 2) оптовий товар [3]. }\end{array}$ \\
\hline Ожегов С. И. & $\begin{array}{c}\text { 1) купівля і продаж товарів партіями, великими кількостями; } \\
\text { Шведовой Н. Ю. товар, який продаєтья партіями, великими кількостями. } \\
\text { Дрібний, великий о.; }\end{array}$ \\
$\begin{array}{c}\text { 2) оптом, про продаж товарів не в роздріб [5]. } \\
\text { Ушакова Д. Н. }\end{array}$ & Продаваний оптом, оптовий товар [10]. \\
\hline Інші визначення & Закупівля продукції як перший етап руху товару від виробника до \\
& покупця [9]. \\
\hline
\end{tabular}

Звернемося до визначень оптової та роздрібної торгівлі, наведених у вітчизняному законодавстві. Так, відповідно до національного стандарту України ДСТУ 4303-2004 «Роздрібна та оптова торгівля. Терміни та визначення понять» оптова торгівля - вид економічної діяльності у сфері товарообігу, що охоплює купівлю-продаж товарів за договорами поставки партіями для подальшого їх продажу кінцевому споживачеві через роздрібну торгівлю або для виробничого споживання та надавання пов'язаних із цим послуг[7]. Роздрібна торгівля - вид економічної діяльності у сфері 
товарообігу, що охоплює купівлю-продаж товарів кінцевому споживачеві та надавання йому торговельних послуг. У цих визначеннях основний акцент зроблено на двох особливостях: розмір партії та споживання.

У таблиці 2представлено порівняння понять «опт» та «роздріб» за рядом характеристик. Як видно 3 таблиці, за більшістю ключових ознак поняття «опт» та «роздріб» ідентичні. Ключова відмінність - розмір партії закупки, що було виявлено при дослідженні визначень категорії «опт» та споживання.

Таблиця 2

Порівняння понять «опт» та «роздріб»

\begin{tabular}{|c|c|c|}
\hline Характеристики & Опт & Роздріб \\
\hline Розмір партії & Кілька одиниць & Одиниця \\
\hline Споживання & Перепродаж & Особисте споживання, \\
& Виробництво & некомерційне \\
& Масове споживання & Готівкова \\
\hline Умови оплати & Готівкова & Безготівкова \\
\hline Кредит & Можливий & Можливий \\
\hline Знижка & Можлива за умови великого & Можлива за умови великого \\
& обсягу купівлі одночасно чи & обсягу купівлі одночасно чи \\
& протягом часу & протягом часу \\
\hline Асортимент партії & Товарна одиниця & Товарна одиниця \\
& Широкий асортимент & Широкий асортимент \\
\hline Продавець & Виробник & Виробник \\
& Посередник & Посередник \\
\hline Покупець & Кінцевий споживач & Кінцевий споживач \\
& Виробник & Виробник \\
& Посередник & Посередник \\
\hline
\end{tabular}

* власна розробка автора

Звернемося до відмінностей понять категорій «опт» та «роздріб» 3 точки зору розміру партії купівлі. Поняття «розмір партії» містить цілий ряд суперечностей:

- по-перше, жодне визначення не вказує на момент переходу опту в роздріб. Посередницькі організації самостійно визначають обсяг продукції, який вважається оптовою партією. Причому цей розмір у кінцевому варіанті може варіюватися під впливом таких факторів: рівень взаємодії між постачальником та покупцем, територіальне розміщення покупця та продавця, умови оплати та затрати на логістику тощо;

- по-друге, жодне визначення не декларує асортимент товарів у партії. Отже, опт може бути партією з різних одиниць товарів, керуючись логікою, що партія це більше ніж один товар; 
- по-третє, за який період має постачатися оптова партія товарів до споживача.

Згадаємо сучасні тенденції в розвитку маркетингу, які варто врахувати для кращого розуміння категорії опт:

- масове виготовлення на замовлення. Сучасні виробничі потужності створюють широкі можливості для виготовлення товару з урахуванням вимог кожного окремого споживача. Споживачі можуть отримувати індивідуальний набір послуг, що робить індивідуальним сукупний продукт. 3 урахуванням сучасних можливостей виробничих та інформаційних технологій, а також сервісної політики, кожний проданий товар є унікальним;

- відтерміноване виготовлення передбачає виготовлення напівфабрикатів з подальшим наданням йому специфічних характеристик відповідно до вимог індивідуального споживача. Такий процес також розмиває поняття опт, адже остаточне виготовлення товару максимально наближається до споживача i часто реалізується за індивідуалізованим запитом;

- спільне споживання забезпечується за допомогою посередницької організації,яка, з одного боку, отримує крупну партію продукції від виробника, а 3 іншого - надає послугу кінцевому споживачу, передаючи продукт у строкове користування за запитом і при цьому не передаючи права власності на цей продукт;

- домінування роздрібної торгівлі та поступове витіснення оптового посередника 3 ланцюга постачання. Фактично, оптову ланку неможливо виключити 3 ланцюга постачання повністю. Оптові посередники, еволюціонуючи, трансформувалися в логістичних операторів або стали частиною вертикально інтегрованої системи крупного роздрібного торгівця або виробника;

- оптимізація логістичних затрат. На сьогоднішній день спостерігається тенденція до зниження логістичних затрат через оптимізацію запасів, зменшення транзитних операцій. Отже, ланцюги постачання можуть складатися 3 виробника та роздрібного торгівця, минаючи оптового посередника та інфраструктуру логістики;

- торгівля «у кредит». Останнім часом роздрібні підприємства не інвестують власні кошти товар, а беруть його на реалізацію, розраховуючись 3 постачальником лише після реалізації товару у власній роздрібній мережі;

- зростання важливості «частки споживання» замість «ринкової частки».

Розглянемовласне споживання, за яким категорії «опт» та «роздріб» також відрізняються. Отже, до опту можна зарахувативсі партії товарів, що постачаються не для особистого споживання, а 3 метою перепродажу та подальшого виробництва.

Висновки. Ураховуючи все вищесказане, можемо констатувати: 
- відбувається розмивання понять «опт» та «роздріб»;

- посередницьке «роздрібне» підприємство перебуває, 3 одного боку, оптовим покупцем, а 3 іншого - роздрібним продавцем, таким чином трансформуючи опт у роздріб;

- розмір оптової партії товару наближається до одиниці, з іншого боку, збільшується кількість трансакцій або кількість різних одиниць товарів у партії.

Усе це вимагає визначити актуальні показники та підходи до розуміння розміру партії товарів, обсягу наданих послуг чи спожитої інформації. 3 розвитком ринку інформаційних продуктів необхідно розробити нові показники вимірювання обсягів споживання, що зумовлено відмінностями процесів виробництва, розподілу і споживання матеріальних продуктів та інформації.

\section{Література:}

1. Басовский Л. Е. Маркетинг: Курс лекций. / Л.Е. Басовский Л. Е.- М.: ИНФРА-М, 1999. - 219 с.

2. Дмитриев Д.В. Толковый словарь русского языка / Д.В.Дмитриев. - М. :Астрель: АСТ, 2003. - 1578 с.

3. Ефремова Т. Ф. Современный словарь русского языка три в одном: орфографический, словообразовательный, морфемный / Т.Ф. Ефремова. - М. : АСТ, 2010. - 699 c.

4. Кузнецов С.А., Большой толковый словарь русского языка / Сост. и гл. ред. С. А. Кузнецов. - СПб. : Норинт, 1998. - 1536 с.

5. Ожегов С.И., Шведова Н.Ю. Толковый словарь русского языка / С.И. Ожегов, Н.Ю. Шведова. - [4-е изд]. - М. : Азбуковник, 1999. - 944 с.

6. Опт [Електронний ресурс] : Веб-сайт Вікісловник, 2014. - Режим доступу : http://ru.wiktionary.org. - Назва з екрана.

7. Роздрібна та оптоваторгівля. Терміни та визначення понять : ДСТУ 4303-2004 - ДСТУ 4303-2004. - [чиннийвід 05.07.2004р.] . - К. : ДержавнийкомітетУкраїни 3 питаньтехнічногорегулювання та споживчоїполітики, 2004

8. Розничнаяторговля [Електронний ресурс] : Веб-сайт Вікіпедія, 2014. - Режим доступу: http://ru.wikipedia.org/wiki/Розничная_торговля. - Назва з екрана.

9. Современный толковый словарь русского языка Ефремовой [Електронний ресурс] : Веб-сайт Академик, $2014 . \quad-$ Режим доступу: http://dic.academic.ru/dic.nsf/efremova/203497/oпт. - Назва з екрана.

10. Ушаков Д.Н. Большой толковый словарь современного русского языка / Д.Н. Ушаков. - М. : Альта-Принт, 2005. — 1216 с. 